\title{
The antinomies of progress
}

The idea of progress came to captivate influential sections of British society in the second half of the eighteenth century. Times were propitious, for after the successful conclusion to the Seven Years War the nation embarked on a course of industrialization and unfettered imperial expansion that was to secure Britain a seemingly unassailable authority in the world order. Domestically, the state enjoyed an unprecedented degree of stability. Revolutionary turmoil of the previous century had been settled, and a unity was being forged by the incorporation of rival national elites into the state apparatus. Challenges to state power from below, while not entirely eliminated, were mitigated by a groundswell of popular patriotism. Control of international markets supplied the wealthy with novel opportunities for conspicuous consumption; a rebuilt metropolis provided public spaces for conviviality and intercourse. This was the impulse of modernization, and it augured well. ${ }^{1}$

The increasingly powerful hold exerted by the idea of progress, however, was predicated on neither consensus nor conceptual rigour. To the contrary, as secular doctrines gained favour, diversity and confusion flourished; the idea could be, and was, articulated in many forms. Taken in general (and retrospective) terms to mean 'the belief in the movement over time of some aspect or aspects of human existence, within a social setting, toward a better condition', its precise expression was determined by the particular assumptions made about historical change, human existence and improvement, and the nature of their interrelationships. ${ }^{2}$

David Spadafora has argued that two doctrines provided the intellectual framework within which the idea of progress developed in eighteenthcentury Britain. The Judeo-Christian vision of history had an ancient lineage in Western thought and continued to exercise a profound influence in discussions on the future of humankind. The second, with a much more recent ancestry in the Renaissance, derived from secular beliefs in the advancement of knowledge. The immanent tensions between these 
doctrines, and the attempts to resolve them, effectively defined the boundaries of the debate on progress, in the process of which both were modified if not transformed. ${ }^{3}$

Christian theology displaced earlier conceptions of cyclical historical time with one that was essentially linear. Progress over time, however, was delimited to the spiritual sphere of human development. Thus while no argument was made for material progress, it was generally recognized among religious thinkers that spiritual improvement through the revelation of divine truth had occurred in the past and would continue in the future. Eventually and inevitably all human kind would benefit by being brought into the faith and wisdom of Christ. Seemingly in tension with this vision was an epistemology that from the time of the Renaissance launched a concerted assault on the authority of the ancients and the scriptures. Advances made in the sciences and in knowledge of successful civilizations beyond the reach of Christianity encouraged secular visions in which progress was attendant on the accumulation of empirically based knowledge of natural and later human phenomena.

The dramatic developments in industrial production, agriculture and transport strengthened the secular vision of progress but never to the extent that it overwhelmed religious orthodoxy. As was so often the case, the frontiers of Christian thought were extended to incorporate - perhaps annul - the challenge. In a deft move, mutually causal links were drawn between advances in the arts and sciences and in religious knowledge. Thus the gradual improvement in knowledge of the world was merely a precursor to the future progress of Christianity. Conversely, such advances in knowledge flowed from and were concrete evidence of the practical application of divine grace. These contrasting visions were therefore integral to the grand design for an earthly utopia, and for many clerics and scientists it was not only possible but desirable to hold on to them both in spite of their seeming incommensurabilities.

Applied to areas of the arts and sciences identified by Spadafora, these arguments are persuasive. Eighteenth-century advances in fine art, medicine, philology, philosophy, medicine and literature were perceived as the irresistible and divinely ordained triumph of the moderns over the ancients. This spirit had pushed back the boundaries of knowledge, and paved the way for future progress. Providentialism, however, was neither as pervasive nor as powerful as he suggests; in one neglected area crucial to Britain's ascent, namely, political economy, divine will featured much less prominently. ${ }^{4}$ The rise of commercial society and the attendant problems of liberal governmentality demanded more systematic forms of knowledge. ${ }^{5}$ Empirical observation combined with Baconian induction had fostered a political arithmetic that was peculiarly suited to the operation and accountability of commerce. Attempts to justify this new moral economy 


\section{THE ANTINOMIES OF PROGRESS}

by recourse to the anthem of progress, however, were replete with difficulty, most notably that associated with the unavailability of reliable data on past societies. To overcome this, conjectural histories that explored the origins of commercial society were forced to rely on distinctly unscientific notions of human nature and providence. What resulted was an awkward synthesis of mathematics, experimental sciences and faith that, in isolating concepts of human nature and mankind, dominated British historiography and philosophy of the eighteenth century. ${ }^{6}$

The failure to provide definitive solutions to these fundamental questions encouraged other forms of knowledge production. Poetry thrived in this period, and of course the novel was born. These imaginative modes of inquiry and representation addressed themselves to precisely the same intellectual concerns as moral philosophy. Thus the writings of Defoe, Richardson and Fielding express in their various ways the valorization and naturalization of commercial society by displacing absolutism with an ethos of liberal governmentality, and promoting the market by stripping individual capitalist activity of the sinful guises imparted by Christian orthodoxy. Now material self-improvement was viewed as an objective, universal and ineluctable principle of human nature and progress. ${ }^{7}$ As we shall see, the influence of these genres in disclosing the nature of poverty and crime gained strength toward the end of the century, and although challenged in the nineteenth by the emergence of systematic techniques of observation and recording they remained a powerful influence on bourgeois and popular perceptions.

In the meantime, the foundations of political economy were being laid, for it was Adam Smith who provisionally resolved many of the tensions in moral philosophy, simultaneously establishing a modern science of commercial society. Smith was able to provide both empirical and theoretical justification by subordinating observable and quantifiable phenomena to abstractions such as society, the market and later the economy in which the divine had no evident or necessary role. Over time, these abstractions became the objects of inquiry, pursued by a professional cohort of social scientists armed with an impressive array of mathematical and statistical techniques.

It was on this intellectual landscape in the latter half of the eighteenth century that certain disturbing features came to be recognized. Poverty, slavery and colonial expansion emerged almost simultaneously as matters of urgent concern, forcing massive shifts in historical consciousness. The presence of the poor, after all, had been acknowledged for centuries; why should anyone seek to challenge the eternal wisdom of Christ's epigram that they would always be with us? Why was it that at this moment the poor were removed from nature and brought into the forefront of history? ${ }^{8}$ Likewise, the existence of slavery had not seriously been questioned since 
ancient times. And yet in this period forces were unleashed that in the space of decades were to bring universal opprobrium to bear on the institution. And why did colonial expansion, which for a time had promised unparalleled prospects of material gain, now seem increasingly a threat to the future of the British nation? This synchronicity has to be explained.

To claim that these issues had resonance because at times of uncertainty they became politically charged is without doubt legitimate. There is sufficient evidence to suggest, for example, that concern about the threatening presence of the poor on the streets of London mounted at those times when their numbers were swollen by large-scale demobilizations. Politics, however, cannot provide a complete answer. The sheer diversity of constituencies that were drawn into debates, and the complex ways in which their concerns were expressed, cannot be explained adequately using the crude analytical tool of political interest. I would like to propose that the idea of progress unified and shaped these anxieties. Within the orbit of modernity, poverty, slavery and colonial expansion came to be perceived as aberrant; the poor, slaves and colonial subjects as defiant. Progress thus acted as an antithetical articulating principle, as a result of which distinctly dystopian visions of degeneration, decline, failure and evil gained currency.

\section{Poverty and progress}

Ancient though the condition of poverty was, the eighteenth century inherited few of the ideological presuppositions that had framed societal perceptions of the poor. Poverty had been thought a state of grace, a misfortune to be borne by the 'holy' poor with pious fortitude and resignation, or a condition to be sought by the devout as an escape from earthly temptation. ${ }^{9}$ Since it was a condition of divine rather than human providence, those who were able were charged out of a sense of Christian duty to provide charitable relief in the form of funds for gainful employment, alms houses and hospitals. Some viewed this as a natural opportunity to display benevolence. Such charity, however, at a time of widespread immiseration attendant on forced displacement from the countryside, proved inadequate, and for the next four hundred years poverty was perceived as a moral, social and political problem to be ameliorated through appropriate measures of relief or control.

Most influential in this were the Elizabethan poor and vagrancy laws, implemented to provide relief to the necessitous poor and suppress potential disruption from those falling outside its ambit. Although private charity remained the preferred option, the principle of a compulsory system of relief implicitly recognized the social nature of poverty. In so doing it also consolidated age-old distinctions between the deserving and undeserving 


\section{THE ANTINOMIES OF PROGRESS}

poor. Those who, through no fault of their own, were reduced to destitution could legitimately claim relief. Others, 'able but unwilling' to work, were refused, and hence forced into beggary where they were subject to the harsh, even brutal regime of the vagrancy laws. In a thesis that has defined much of the subsequent debate, Richard Tawney locates these new legal forms within the shift that took place in the consciousness of poverty. Protestantism - or more precisely its urban manifestation, Calvinism broke with a Christian tradition that had regarded commercial activity as sinful. In contrast to the damning indictment of profit as the illegitimate gain of parasitical entrepreneurs and usurers, Calvin and his followers preached that profit, if not excessive, was income accruing from respectable industry and diligence. Indeed, by seeking not personal salvation but the glorification of God, commercial activity was practical devotion. It was a theology that both expressed and drew support from an ascendant merchant class, for

it no longer suspects the whole world of economic motives as alien to the life of the spirit, or distrusts the capitalist as one who has necessarily grown rich on the misfortunes of his neighbour, or regards poverty as in itself meritorious, and it is perhaps the first systematic body of religious teaching which can be said to recognize and applaud the economic virtues. ${ }^{10}$

These economic virtues had their basis in labour, not only of capitalists but also of the poor. In a move that enshrined economic progress in religion, idleness was now acclaimed as a sin against God and society. The putative state of grace of the pauper was no longer defensible, nor was indiscriminate alms-giving; instead, a system of secular relief dictated that those who could work but were prevented from so doing by economic depression should be set to productive work, and those who could not work should be aided with relief.

Much as the Elizabethan poor law was celebrated as emblematic of a modern civilized nation, its legacy was uncertain. It was never designed to be the principal means of relieving economic distress, merely one to be used as a last desperate resort. Its founders anticipated that private philanthropy would continue to meet most of the need; in the event it did not. Furthermore, successive cohorts of legislators, acting out of a belief that prevention of destitution was better than a cure, sought to guarantee regular income by stabilizing employment, and to control the prices of staple foods, in particular bread, by eliminating restrictive practices. ${ }^{11}$ None of this was successful in mitigating distress, and as pressure mounted on the system in the seventeenth and eighteenth centuries, so its actuarial and administrative foundations began to crumble.

Attitudes toward the system of relief hardened. Puritan zeal of the seventeenth century turned the critical gaze of individualism on the causes of 
distress and found there moral deficiency. The result was a renewed assault on idleness. Relief, in whatever form, was thought enervating since it discouraged the poor from seeking work; the only long-term solution was to reform their character, if necessary by compulsion. Thus the idea of forced labour for all able-bodied poor made sound moral and economic sense, and found increasing acceptance among religious and business communities. Morally, such labour instilled the values of thrift, sobriety and acceptance of subordination within a rigid social order; economically, it reduced the pool of unproductive labour and the diversion of precious financial resources in relief of destitution to the benefit of nation and empire. It was an ethos that combined personal and national salvation. Thus were established in broad outline the principles that were to culminate in the 1834 Poor Law Amendment Act, not in the event for the salvation of the nineteenth-century poor, but their damnation.

Even if the agenda of the voluminous debate on poverty during the eighteenth century had been decided from the outset, sharp divisions of opinion emerged. The dialectic of the moral and economic was sufficiently expansive to allow, even encourage, diversity; indeed, it is only with difficulty that we can provide a degree of coherence to the mass of comment. ${ }^{12}$ If there was a common theme it was that of labour, for in an age of mercantilism productive labour provided the key to national prosperity and stability. Most writers in the early decades who addressed themselves to the question of poverty used this as the touchstone. Thus when Daniel Defoe in his 1704 pamphlet Giving Alms No Charity, and Employing the Poor a Grievance to the Nation railed against proposals for a variety of schemes to put the poor to work, he did so on the grounds that the work created no new industry. ${ }^{13}$ When Bernard Mandeville satirized the moral and social evil of the time in The Fable of the Bees, he castigated the idleness of labourers and the hypocrisy of charity. ${ }^{14}$ And the Rev. Thomas Alcock, writing on the poor law in 1752, identified the baneful influence of luxury. Touching on one of the most significance debates of the time, he blamed the poor law for promoting the evil it was intended to remedy. Relief served only to promote indigence by encouraging a taste among the poor for luxuries such as tobacco, tea and dress of little service. ${ }^{15}$

This paradigm was challenged if not overthrown by the emergence in the second half of the century of writers associated with the Scottish Enlightenment, most notably Adam Smith. As we have suggested, although Smith's political economy tilted the balance of thinking on progress toward more secular perspectives, moral philosophy evidenced in concerns over the human condition was never excised completely. In no area was this more apparent than that of poverty. Because human progress and prosperity were believed to attend the pursuit of self-interest in a market economy untrammelled by state interference, this did not mean that 


\section{THE ANTINOMIES OF PROGRESS}

responsibility for the poor could be abrogated. The 'wealth of nations', after all, referred not to their monetary power but to their peoples. ${ }^{16}$ No nation could be 'wealthy' that condemned the majority of its people to a life of abject poverty, and so it was a matter of urgent concern that the conditions of the poor be improved. Any system guided by the principles of high prices and low wages could not guarantee the nation's wealth. Instead, fair and liberal rewards for labour should be promoted by a 'progressive' economy since they encouraged the poor to pursue self-interest actively and conscientiously. Interference in this 'natural' mechanism was to be resisted. Thus settlement laws limited the mobility of labour, and were an affront to liberty and justice. ${ }^{17}$

Trade cycles, war and settlement laws also exacerbated the seemingly intractable problem of vagrancy. Vagrants had first been defined as a source of social and political concern with the introduction of Elizabethan vagrancy laws; indeed, we tend still to think of vagrancy as a problem of early modern England. Agricultural dislocation swelled the ranks of socalled masterless men who were forced to take to the roads of the country in search of gainful employment. ${ }^{18}$ More than the poor who fell within the cold embrace of the poor law, 'vagabonds and incorrigible rogues' were potent symbols of transgression in a society that increasingly valorized Protestant virtues of hard work, thrift, order and personal responsibility, and as such they were subject to a brutal regime of sanctions from whipping and branding to transportation and execution. ${ }^{19}$

Toward the end of the seventeenth century the problem of vagrancy seemed to ease. Enhanced economic prospects and increased poor law expenditure forced fewer into transient poverty. The disciplinary regime became less bloody. Vagrants were less likely to be identified and punished as vagabonds; rather, when apprehended, they were removed to their place of settlement where they were entitled to poor relief. By the beginning of the eighteenth century, the vagrant population in the countryside comprised largely itinerant Scots, Irish, gypsies, entertainers and the exmilitary. ${ }^{20}$ The large cities, however, presented a different problem. London in particular drew the desperate masses of the poor displaced from the countryside. Here was concentrated untold wealth to be tapped by the various skills of beggars, tricksters and thieves. In the climate of eighteenth-century improvement, it was this constituency that came to be seen as the principal barrier to progress. ${ }^{21}$

\section{Slavery and progress}

Although the existence of slavery had since ancient times attracted the critical attention of social and moral commentators, it was not until the eighteenth century that discussion featured prominently in the influential 
works of moral philosophy and political economy. ${ }^{22}$ At the heart of this concern was a desire to explain why slavery continued to flourish in an age of progress, and in the New World which so embodied the ideal. For potential answers Enlightenment thinkers, political theorists and theologians looked to the historical record and the troublesome concept of the natural order. Many resolved that there was a fundamental contradiction between the perpetuation of slavery and human progress, and that any progress to a new era was predicated on abolition of the slave trade and emancipation of slaves.

David Brion Davis has convincingly demonstrated that the history of modern Western slavery and emancipation can be recast around the notion of progress. The relationships between changing conceptions of slavery and progress, however, are highly mobile and ambiguous. There was little evidence of anti-slavery sentiment before the eighteenth century. It is a profound paradox that while prominent thinkers, heirs to the seventeenth-century revolution, were laying the theoretical foundations for political liberty, they accepted slavery as a natural state. Thus when John Locke in the First Treatise of Government declared that 'Slavery is so vile and miserable an Estate of Man, and so directly opposite to the generous Temper and Courage of our Nation; that 'tis hardly to be conceived that an Englishman, much less a Gentleman, should plead for ' $\mathrm{t}$ ', the estate of man he had in mind was that found in a free and rational society governed by social contract. The enslavement of Africans, on the other hand, conformed with natural law since it derived from the legitimate purchase and domination of captives of war. Such slaves were private property and were subject to the same valid morality. ${ }^{23}$

The sources of anti-slavery thought in the eighteenth century were diverse and complex. British Protestantism was in the early vanguard, and because of this it is tempting to view the stirrings of abolitionism as part of a Christian philanthropic tradition galvanized by mounting concern over the poor. The chronologies, however, were discrepant. Furthermore, Protestant attitudes to private charity and institutional relief were weakened by the belief that undue zeal in the pursuit of benevolence and promotion of self-reliance among the poor would undermine the social order, and as such could not provide the basis of a concerted assault on slavery. Slavery, however, provided a sufficiently remote test bed for Protestant morality since, unlike the poor law, it was an institution that could be challenged without the same threat to domestic social and political relations. ${ }^{24}$

Quakers in Britain were the shock troops of the abolition movement. As one of the most powerful groups to emerge from the sectarianism of the seventeenth century, Quakers retained internal unity and identity against an intolerant religious order, and directed spiritual energies to the practical alleviation of social problems. Commerce was one of the few spheres from 


\section{THE ANTINOMIES OF PROGRESS}

which they were not excluded, and through extensive, mutually supportive networks and a reputation for honest trading, Quaker families were able to build substantial banking and manufacturing empires. Initially, their economic interests were so tied up with the slave trade that active involvement was inevitable, but in the course of the eighteenth century this became increasingly untenable. Unable to make the moral compromises of more orthodox churches, the Society of Friends came to view slavery as a moral evil, and in the 1760 s took the first steps on the path to its eradication.

Within two decades the cause had attracted a rather larger body of converts. In the 1770s John Wesley was alerted to the nature of slavery by a pamphlet written by the Quaker Anthony Benezet, and mobilized Methodists behind the abolition movement. To Wesley slavery represented the ultimate violation of justice, mercy and truth, and everyone involved in the villainous trade was stained with blood. Redemption was to be sought in emancipation. ${ }^{25}$ These ideas appealed widely to revivalist sentiment in that they provided a way out of the spiritual difficulties faced by many who thought that religious orthodoxy had reached a self-created impasse of meaningless and abstract speculation. Anti-slavery was a cause that could be used to express Christian devotion in direct and practical forms. Few Methodists, however, could sustain Wesley's uncompromising stand. Even his most notable follower, the slave ship captain John Newton, who experienced conversion during one of many voyages, was initially reluctant to condemn the trade. It was only later he decided to speak out publicly in order to bring to public attention the evils of the trade. Such faltering progress was emblematic of evangelicalism as a whole, and suggested its future course, for the 'main thrust of eighteenth-century revivalism ended with the missionary, not the abolitionist'. ${ }^{26}$

Slavery, like poverty, attracted the attention of more secular and rational modes of inquiry in this period. Here again the influence of thinkers of the Scottish Enlightenment was of particular significance, in part because it was rather less ambivalent than its French counterpart. Drawing upon the work of contemporaries such as Francis Hutcheson, John Millar and Jacques Turgot, Adam Smith condemned slavery by locating it within schemes of economic and moral progress. Slavery, he argued, confronted directly the laws of morality and utility. The development of mutual identification and self-interest, upon which harmonious social relations and economic progress depended, was threatened by the perpetuation of the slave trade. Its eradication would unshackle progress from those artificial restraints that had been sustained by monopoly and special privilege, allowing self-interest to be harnessed to the general good. ${ }^{27}$

As a result of these various impulses, mediated in highly complex ways from the late 1760s, modern slavery was viewed with increasing concern 
as an evil, regressive and inefficient institution. This constituted a profound shift in historical consciousness, leading eventually to the abolition of the slave trade and the emancipation of black slaves. Much historical attention has been devoted to the role of organizations such as the London-based Society for Effecting the Abolition of the Slave Trade, established by the Quakers in 1787, and the Clapham Sect loosely based around William Wilberforce after his famous speech in parliament on the slave trade in 1789. These bodies, however, were able to draw upon a groundswell of popular opposition to slavery throughout the country, much of it galvanized by the activities of countless women. ${ }^{28}$ Campaign activists or those who provided its moral and economic rationale anticipated abolition would promote material and moral progress. In the event, the legacy of slavery and abolition was rather more ambiguous and uncertain. ${ }^{29}$

\section{Colonialism and progress}

In the first half of the eighteenth century Britain emerged as a mercantile, imperial and naval power to rival France, Spain and Holland. Structurally underpinned by mutually supportive relationships among the state, the navy, and financial and mercantile sectors, British influence increased not only in global markets, but also in those ancillary services such as insurance, shipping, banking and distribution that were vital to continued growth. ${ }^{30}$ The series of naval and land victories during the Seven Years War established Britain's supremacy by effectively stifling the ability of rival powers to develop overseas trade while that of Britain actually expanded. ${ }^{31}$ The triumph over the French in North America was so complete that France's presence in other parts of the European empire was greatly weakened; most importantly, Britain was able to make significant gains in India, most of them at the expense of French interests. The profound sense of confidence that prevailed at the close of hostilities in 1763, however, was relatively short-lived. Within twenty years the British empire seemed on the brink of collapse.

A number of circumstances combined to sap belief in the progress of the 'first' British empire. Loss of the American colonies had revealed the limitations of Britain's fiscal strength, for when the state attempted to recoup the enormous cost of the Seven Years War by taxing the colonies it had claimed to defend, resistance mounted, precipitating the American War of Independence. Furthermore, the nascent empire in India was threatened by the endemic mismanagement and profligacy of the East India Company, and a rising tide of anti-colonial struggles. And the French, strengthened after fiscal reform and through retention of the most lucrative of the slave colonies, St Domingue, began to challenge Britain's 


\section{THE ANTINOMIES OF PROGRESS}

control of the Caribbean slave trade. Finally, nationalist unrest in Ireland served to remind the British state that its oldest and nearest colony continued to be a source of real concern. ${ }^{32}$

For many, these events flowed inevitably from the logic of a flawed imperial ethos. From the early stages of expansion in the seventeenth century Britain's role had been defined by a distinct sense of imperial authority, much of it derived from ancient and medieval legacies. The Roman notion of Imperium described the limited but absolute authority of a single individual over a territory embracing more than one political community. In medieval Europe, this was appropriated by an ascendant Christian church to forge an empire - Christendom - in which the cultural and religious diversity of the Roman empire was superseded by a single sacred authority. ${ }^{33}$ Armed with this authority, and claiming a mission to civilize the rest of the world by converting its inhabitants to Christianity, European powers embarked on various imperial projects, notable for their brutal exploitation of indigenous peoples.

While elements of this universalism survived well into the nineteenth century, it came under increasing attack from elites in the imperial metropolises. Early writings like Bartolome de Las Casas's A Short Account of the Destruction of the Indies (1552) had expressed moral outrage at the genocidal Spanish conquest of America, and a fear that Spain would be visited by divine retribution if not stopped. ${ }^{34}$ More influential, however, were the later critiques that such imperial ambition was politically and economically destructive. The experience of Spanish, French and British overseas expansion, it was argued, demonstrated that every settler community eventually came to demand political autonomy and economic self-sufficiency, and that exploitation of forced labour - either indigenous or imported slave - was economically inefficient, not least because it was massively destructive of human life. ${ }^{35}$

Perceived here was a tangible threat to progress of the imperial state. In a pleasing irony, the ancient Imperium was now used to confirm a teleology of self-destruction. Just as the Roman empire had collapsed under the inexorable logic of extravagant territorial expansion, so European empires would fall into ruin unless the relationship between colony and metropolis was reordered to prevent the needless drain of vital resources. As David Hume, one of the most consistent critics of expansion, stated:

There seems to be a natural Course of Things, which brings on the destruction of great Empires. They push their Conquest till they come to barbarous nations, which stop their Progress, by the Difficulty of subsisting great Armies. After that, the Nobility \& considerable Men of the conquering Nation \& best Provinces withdraw gradually from the frontier Army, by reason of its Distance from the Capital \& barbarity of the Country, in which they quarter.... Hence Disorder, Violence, Anarchy, \& Tyranny, \& Dissolution of Empire. ${ }^{36}$ 
Evidence for the corrosive influence of territorial expansion could readily be found at the limits of empire in America and India. Colonists in America, armed with the rhetoric of liberty, were pressing for a degree of political representation with such urgency that total separation and the attendant collapse of empire seemed only a matter of time. Meanwhile, the corruption, greed and inefficiency attached to the activities of the East India Company were seen to threaten not only British possessions in India but somehow through diffusion the very fabric of metropolitan culture and polity.

The solution was sought, as it was to the problems of poverty and slavery, in the enlightened languages of moral philosophy and political economy. ${ }^{37}$ Thus from the 1730 s the providential spirit of conquest and the pursuit of military glory were displaced in Britain by an ethos that emphasized the mutual interdependence of commerce, Protestantism, maritime power and liberty. ${ }^{38}$ This was none other than a British national identity, in the process of being forged from components of a culture reaching back to the sixteenth century. Liberty was enshrined in the invented tradition of an ancient English constitution manifest in a system of law that guaranteed rights for all of its subjects. This was underwritten by a Protestantism that set Britain apart from those European powers seen to be suffering under Catholic oppression. In the eighteenth century, the notion of an elect nation was displaced by one that increasingly embraced Britain's wider role as a rising commercial and naval power. ${ }^{39}$ Here the influence of political economy was telling. In India, for example, board members of the East India Company constantly turned to the writings of the new breed of political economists for guidance. During the crisis of 1771 when faced with financial chaos they approached the leading economist, James Steuart, to report on the situation. ${ }^{40}$ And despite the hostility of Adam Smith to the monopoly of the Company, the directors were prepared to ask him to participate in an inquiry into administrative malpractices. These instances were symptomatic of a general acceptance that commerce under the guiding hand of political economy should temper the influence of paternalism and evangelism in the economic affairs of the Company.

Ostensibly uniting the interests of Irish unionists, Glasgow merchants, Caribbean planters and officials in the thirteen colonies with those of the British state, this ethos provided an integrated empire within which individual rights and private property were secured. Imperium was unitary; Dominium divided. ${ }^{41}$ Such a conception of empire found ready acceptance throughout the British Atlantic world as the various constituencies came to think of themselves as members of a single community - the 'British empire' - pursuing their commercial interests in a just and peaceful manner. Significantly, it also came to command in Britain during the 1740s a 


\section{THE ANTINOMIES OF PROGRESS}

genuinely popular following. 'Rule, Britannia' dates from this time.

This Imperium, however, contained the seeds of its own destruction, for the political principles exported to the American colonies, particularly those governing rights, property and the common good, were readily appropriated against metropolitan authority. The rebellion of the thirteen colonies pushed these principles to the limit and then fractured them. ${ }^{42}$ With their cession, and the revolutionary challenges that ensued, the dominant rhetoric of empire took on more authoritarian and hierarchical dimensions. Crown, Church and Constitution were appointed as its guardians; in their names new instruments of coercion and control were implemented that expressed and fostered an institutionalized ethos of racial superiority. ${ }^{43}$

From the putative crisis in the imperial state emerged a new empire. Although we must caution against crudely drawn boundaries, the second British empire was geo-politically and ideologically distinct. The turn to the East in a changed world order was accompanied by this new imperial ethos. That deriving from the 'medieval legacy of universalism', a presumed right of lordship, or from the pan-Atlantic Imperium, had no relevance to the role of the British state in India and Africa. Rather, the imperial ideology that underpinned the 'aristocratic authoritarianism' or 'proconsular despotism' of the state ${ }^{44}$ was articulated to a newly forged British nationalism; ${ }^{45}$ together they charted the course of the state in reestablishing the empire, and defining its attitudes toward colonial subjects.

This study is an attempt to understand something of the nature of the process by examining the homologies that existed between discursive constructions of colonial subjects and the metropolitan poor during the long nineteenth century. To my mind there were unmistakable parallels in their chronologies and rhetoric, and in the agencies that were responsible. If this is the case, then it follows that the perceived problems around colonial expansion, slavery and poverty have to be recast within the dynamic relationship between metropolis and empire. But before we come to explore the evidence, it is necessary to think further about the claim made at the outset that the articulating principle for these concerns was that of progress. To do this I wish to consider the thinking that informed ideas of progress, and why certain peoples were seen as barriers to imperial modernity.

\section{Progress and the human order}

Lecturing at Swarthmore College in the troubled year of 1941, the redoubtable Arthur O. Lovejoy had good cause to reflect on the transformation he had witnessed in human thought. He cited with approval Max 


\section{THE OTHER EMPIRE}

Lerner's declaration that 'the rational, right-thinking man has as surely ceased to be considered the center of our intellectual system as the earth has ceased to be the center of our planetary system' ${ }^{46}$ This revolution, Lovejoy proceeded to explain, had its counterpart in the seventeenth and eighteenth centuries, for the writers of that age also were preoccupied with the attempt to understand the irrational in human nature and how it was linked to progress. That they lacked the rigour or analytical insights of their successors is not in doubt; that they were less penetrating in their analysis is.

Some appreciation of this revolution will, I believe, enable us to understand better the complex and dynamic relationship between conceptions of progress and human nature in the eighteenth century, and thereby the reasons why different constituencies were subject increasingly to processes of social, cultural and political exclusion. Conventionally, these processes have rightly been seen as integral to the development of modernity in its capitalist or imperialist guises. ${ }^{47}$ Such perspectives, however, in defining progress as capitalist or as endemic to Western societies - with very different experiences of colonialism and capitalist modernization beg rather more questions than they answer. The identity made at the outset, therefore, between the emergence in mid-eighteenth-century Britain of ideas of progress and the new-found confidence in commercial and imperial activity is not as secure as it might first appear. For while a sense of material improvement did undoubtedly contribute to the acceptance of progress, it cannot explain fully why, for example, progress was seen differently in England and Scotland, or indeed why belief in progress existed at all. ${ }^{48}$ Historical pessimism, after all, was a powerful current in intellectual thought and survived to feed nineteenth-century visions of decline and degeneration.

Ascent of the belief in progress has variously been attached by scholars to advances in Christian conceptions of history, the secularization of thought in the arts and sciences, and changing views of human nature. ${ }^{49}$ Rarely considered in this diverse body of work, however, is how a celebration of belief in progress structured conceptions of the human order. I wish, therefore, to revisit these broader themes, specifically the great chain of being and the stages theory of historical development, for it was these that came to define the contours of progress and to identify its most potent enemies.

Such is the status of the great chain of being that it is conventionally capitalized. Its lineages can be traced to ancient Greek philosophy, but its real significance dates from the Middle Ages when as a plan of the universe the conception came to be accepted without question by the majority of educated opinion. ${ }^{50}$ This was to remain so until the ascent in the nineteenth century of evolutionary theory. The guiding principles were pleni- 
tude, continuity and linear gradation. Providence had created nature, it was contended, as an infinite number of beings ranging from the lowest forms to man. These beings were linked to one another in hierarchical order, differing from that immediately below and that immediately above by such minute gradation - the least possible degree of difference - that it was impossible to determine the point at which one ended and the other began.

Although details of the underlying principles were viewed differently, these mattered less than the social and political consequences that flowed from the scheme in its totality. Plenitude was proof of God's existence because it demonstrated his cosmic beneficence, but simultaneously it gave support to the curious notion that nature had been created for the use of mankind. This anthropocentrism was tempered, however, by the recognition that man's location in the chain was well below that of the supreme being. Locke, for example, was persuaded that there was a far greater number of species above us than below us, and Kant surmised that higher beings viewed a Newton as 'we view a Hottentot or an ape'. ${ }^{51}$

This 'ethics of prudent mediocrity' confirmed man's station and the immorality of pretensions higher or lower. Wisdom began with knowledge of one's limitations. To strive for intellectual achievements beyond the meagre capacity of man was to commit the sin of pride. To pursue innate animalistic tendencies was to become degenerate. Either act was a threat to the balance of a universal system in which all beings were allotted a place..$^{52}$ It was one short step to apply these arguments to the social and political spheres of human activity. Imperfections may exist, it was surmised, in forms of government, but since these resulted from weaknesses in human nature any attempt to transform society through political action challenged the divine order. Society was maintained through the same set of principles. God had appointed all to their particular station in life. Those in lower estates had just cause to claim respect and consideration from their superiors, but demands for equality were an affront to nature. It was a profoundly pessimistic and conservative vision.

It was possible, however, to derive an antithetical, optimistic vision from the principle of plenitude. Imperfections exist in the providential design because they are necessary to the perfection of the whole and this to the common good. The limitations of each species of being define its place in the great chain, and so it is futile to ask why none is endowed with greater talent. Any alteration threatens the integrity of the organic world and hence its happy ordering. This was the vision that impelled much of the work of natural scientists as they sought proof of the ways in which every creature was endowed with characteristics consistent with, indeed necessary to, the perfection of the whole. But such inquiry cleared the ground for an approach that directed attention less to final causes than to 
origins, and hence the problem of evolution. ${ }^{53}$

The idea of least possible gradation as static and fixed began to be challenged by philosophers and scientists anxious to explain the possibility of movement from one species to another. The belief that upward movement, even if possible, was to the cost of those occupying the next order, gave way to the notion that general progress was achievable. Biologists and geologists, increasingly aware of the evidence on plenitude, sought to explain gaps in the chain. Here the relationship between humans and apes took on a particular significance. Although physical similarities between the two species had long been recognized, no one was yet bold enough to suggest that humans were the descendants of apes; instead, connecting links were sought. Invariably, the 'savage races of Africa' were identified in intellectual, physical and moral terms as the most likely sources. ${ }^{54}$ The temporalizing of the chain of being, therefore, while opening the window to progress, simultaneously codified potential barriers to it.

This was a distinct reversal to another influential current of thought in eighteenth-century Britain. Primitivism was an historical and ethical philosophy that from at least the fifth century BCE had dominated Western thought on the historical development of human society. At the heart of the philosophy was the belief that early human society displayed noble qualities that in the course of time had been corrupted by the march of civilization. Thus essential human qualities such as goodness, kindness and wisdom were found in primitive society; now evil, greed and pride prevailed.

Toward the close of the eighteenth century, the influence of primitivism reached its zenith. The explorations of North American Indian and South Sea Island societies in the second half of the century gave considerable impetus to the primitivist critique of advanced Western society. In extolling the virtues of the simple life of nature it ran as a powerful current against the degenerative tendencies of luxury and pride endemic to industrial civilization. Luxury was of particular concern. As a concept it was sufficiently imprecise to engage the interests of most of the important and many of the popular writers of the age, and to be used by them as a talisman to express fears about a diverse range of social and political pathologies. ${ }^{55}$ Much of this was inherited from the ancients. Luxury had long been regarded as a fundamental evil from which others ensued, and it was seen to be virtually limitless as human desires multiplied. In its most potent form luxury was against nature for it threatened to undermine the providential order of the chain of being, or was confirmation of historical regression. And luxury was ubiquitous. It was found in the church, in Westminster, in aristocratic mansions, in merchants' houses, but most evidently among the people. As was so often the case when social concern was expressed, only others were seen as corruptible. Hence the plebeian 


\section{THE ANTINOMIES OF PROGRESS}

rabble, prone to licentiousness, and damned by excessive consumption of tea and tobacco, were identified as the single most toxic threat to civilization. Unless checked by moral or legal restraint, tyranny and barbarism would ensue.

Luxury became a particularly powerful weapon in the hands of the political opposition. The extreme suspicion with which more radical elements in the eighteenth century viewed political authority derived in large part from their hatred of the enervating influence of luxury. ${ }^{56}$ Leaders, upon whom the future of the state depended so heavily, were diverted from serving the common good by the selfish and vainglorious pursuit of property. Corrupt and unprincipled government was the result. Dr John Brown - one of the most astute and widely read critics - wrote at a time of personal and political crisis 'to throw just light on the peculiar causes of our calamitous situation'. Among the few remaining virtues, he argued, were the spirit of liberty, humanity and the civil administration of justice, but these were assailed by the spirit of commerce, which 'begets a kind of regulated selfishness', and engenders in the character and manner of our times a 'vain, luxurious, and selfish EFFEMINACY' ${ }^{57}$ And in a revealing passage, he politicizes the chain of being to suggest how corruption in high places leads to the dismantling of political order in the same way as ambition threatens the natural order:

Thus the great chain of political self-interest was at length formed; and extended from the lowest cobbler in a borough, to the King's first minister. But a chain of self-interest is indeed no better than a rope of sand: There is no cement nor cohesion between the parts. ${ }^{58}$

Pride was further evidence of human corruption. Material advantages and intellectual superiority over other beings, it was argued, engendered artificial desires and false vanities that disrupted man's harmony with nature. ${ }^{59}$ The contemporary passion for approbativeness, self-esteem and emulation exemplified unconscious and non-rational pride that had set humans apart in the chain of being, and on a path increasingly divergent from reason and virtue. Mandeville's Fable of the Bees, for example, one of the most virulent social critiques of the eighteenth century, can be thought of as a damning indictment of irrational motives. In tracing the connection between 'private vices' and 'public benefits', he singled out pride as the trait upon which morality seemed to depend. ${ }^{60}$ Only by returning to the humility of primitive peoples was moral redemption possible.

The intellectual and moral thrust of this complex but unifiable discourse shifted dramatically in the second half of the eighteenth century. Primitivism entered into crisis when it appeared to have reached its apotheosis. Part of the problem was that the philosophy, like that of the great chain of being, was so fluid that it could be used to arrive at contrast- 
ing interpretations of progress. The putative record was consistent with doctrines of both the inevitable decline and the constancy of human nature once the original state of innocence had been lost. ${ }^{61}$ For some it could provide a programme of progress by reversion to the original state of nature. At that moment when events in science, economics and philosophy moved against it with unprecedented vigour, primitivism collapsed under the weight of its immanent logical inconsistencies. By 1788 Joseph Priestley - hardly a conservative - could claim that 'Idleness, treachery and cruelty are predominant in all uncivilized countries; notwithstanding the boasts which the poets make of the golden age of mankind, before the creation of empires'. ${ }^{62}$

The ideological props of primitivism were also assailed. Strands of Augustan and Enlightenment thought began to question the deleterious effects imputed to luxury and pride. The sceptical Johnson claimed that since luxury could only ever reach the few, no civilization was ever damaged by it. To the contrary, the poor are strengthened by material gain. And Gibbon, conventionally seen in his classic study of the fall of the Roman empire as an arch-enemy of luxury, actually made a subtle distinction between different forms. In an imperfect society, he argued, luxury is an effective means of mitigating inequality; only when it is pervasive, as in Rome before its fall, does luxury become 'a secret and destructive poison'. ${ }^{63}$ More vigorous and telling, however, was the reassessment launched by political economists. Integral to their critique of primitivist theories was the valorization of commerce as a progressive stage in human development. Far from acting as a destructive influence on development, the desire for luxury, manifest in material improvement, was now seen as one of its principal motor forces. Ferguson, Millar and in particular Adam Smith argued cogently that commercial progress required the unfettered pursuit of material interest. The prospect of material gain, therefore, encouraged Protestant virtues and enhanced social stability.

In a similar vein, the dissembling influence of pride was rethought. Pride in its various manifestations came increasingly to be viewed as the inspiration for virtuous action and progress. Hume based his theory of moral judgement on the premise that the desire for self-esteem derives from approbativeness, and encourages virtuous behaviour since people are driven to act in ways that appear to others praiseworthy. Affection not rationality thus controls human volition. Smith also recognized the power of approbativeness, and conversely that of disapprobation and disapproval. Humans are endowed with a desire to please, and any feelings of self-love must be subordinated to the desire for admiration from others. This genuine human need for prestige fosters also a desire for material possession - an argument that in the Theory of Moral Sentiments came to be erected as the theology of commercialism. ${ }^{64}$ Ownership of private 
property, he stated, was based on the need for emulation and honour; 'there is no other conceivable incentive to the accumulation of wealth' ${ }^{65}$

This transformation in thinking on degenerative tendencies was framed by wider concerns of Enlightenment thinkers to valorize commercial society as the logical culmination of a distinct trajectory of historical change. ${ }^{66}$ The publication of Locke's Two Treatises on Government in 1690 had opened the path for a stages theory of development. His discussion of the historical origins of property challenged ancient and scriptural accounts by suggesting that the more primitive modes of subsistence were not coexistent in the earliest ages of Asia and Europe, but rather were evidence of progress over time. ${ }^{67}$ It was a path, initially, that few eighteenth-century writers were willing to follow. Mandeville, Hutcheson and Montesquieu all thought of stages in societal development, but their treatment of economic factors was fragmented and lacked coherence. With political economy, however, the stages theory of development reached maturity. Seminal thinkers such as Smith, Turgot and Quesnay constructed an overarching and teleological scheme of socio-economic progress through distinct and successive stages - defined essentially by their mode of subsistence - which embraced at one pole primitive societies witnessed in America and the South Pacific, and at the other advanced commercial economies. Thus the economy, like history, was seen to work to certain laws, the study of which could be pursued through comparisons of the division of labour, commodity exchange and accumulation of capital in different forms of society. ${ }^{68}$

The geo-politics of development derived from the work of the sixteenth-century political theorist Jean Bodin, who had reinterpreted the course of human history by identifying three crucial periods, each dominated by the peoples of a distinct region of the globe. The first two millennia had been dominated by the so-called Orientals (Babylonians, Persians and Egyptians), not because of their productive power, but because of their unrivalled hold over religion, philosophy and mathematics. Mediterranean peoples (Greeks and Romans) dominated the next two millennia because of their politics and practical knowledge, to be displaced by Northern peoples (Europeans) through their skills in warfare and mechanical inventions, and their ability to advance the scientific and philosophical work of the ancients. ${ }^{69}$ Incommensurable though this geo-politics was with a stages theory of development, from the 1760s elements of the two theories were combined imaginatively to give even greater weight to the teleology of the West's ascent.

It was at this moment that Western civilization was invented. ${ }^{70} \mathrm{~A}$ somewhat awkward synthesis of ideas on intellectual, artistic and scientific ability, socio-economic and political progress, historical narrative and geo-politics, it served to consolidate the self-identity of the West, in part 
and increasingly by the exclusion both of subordinates and of non-Western peoples as lower others. This transformation in thinking about the human order thus had a profound impact on the ways in which its various constituencies were viewed. To appreciate this issue more fully we need to consider the history of conceptions of difference from the time of the Renaissance when the other first entered into the European imagination as an object of concern.

Until the sixteenth century, the relationship between European and other was framed by a Christian cosmography that inherited medieval forms of classification. ${ }^{71}$ Within this, savages were defined principally in terms of the religion they lacked, that is, as pagan, heathen or monstrous disciples of the devil. The 'discovery' of the Americas by Columbus and the tradition of travel and exploration that followed created a revolution in the geographical imagination. No longer could the world be seen in Ptolemaic terms as a relatively small island, centred on Jerusalem and surrounded by limitless and unknowable expanses of water; instead, it was recognized as a land surface forming a continuous whole, contiguous with but not bounded by oceans.

This integrity posed new challenges. The Christian subject may still be held to occupy the centre of the new geographical order, but he is brought forcefully into a relationship with peoples occupying the newly discovered spaces. The extraordinary period of exploration following Columbus emphasized the point. Travel accounts based on more reliable empirical observation displaced the medieval fantastic and monstrous by asserting the essential humanness of other peoples, and the necessity of bringing them into the European conceptions of the human order. To deny their humanity was to depart fundamentally from contemporary theological orthodoxy based on Genesis and the teaching of Moses that humankind possessed an essential unity, and that there was nothing in the colour of a person's skin that could suggest otherwise. An urgent question thus arose: if Indians - both of the Americas and the East (rediscovered by Vasco Da Gama in 1498) - are beyond the Judeo-Christian world, but nonetheless the brothers and sisters of Europeans, then how can they be located?

The answer was to be sought and found in the great chain of being. In a double movement of exclusion and incorporation, the savage was subordinated to the European as an ignorant and uncivilized non-Christian, but one capable of conversion. It was primarily through the lens of Christianity, then, that knowledge of the manners and customs of alien peoples was sought, not to understand and explain, but as a means of incorporating them into the European order. In the course of the eighteenth century, as the idea of progress took hold, so a spatially ordered hierarchy became a temporal one: 


\section{THE ANTINOMIES OF PROGRESS}

With the Renaissance revival of historiography, with the decline of degenerationism as a philosophy of history, with the insistence of the 'moderns' on their superiority over the 'ancients', with the idea of cultural progress, the hierarchy of being had to be converted from a spatial arrangement of forms into an historical, developmental, or evolutionary series. ${ }^{72}$

Contemporary savagery thus came increasingly to be identified with ancient stages of other cultures. At first sight this appeared an unlikely and implausible move. Evidence suggested few similarities between ancient societies and those of African or Indian natives. Nor could it be argued convincingly that savage cultures displayed any degree of uniformity. And yet by this identification contemporary native societies were condemned as degraded, and savages occupied the places previously reserved for human monsters. An order of contemporary difference was transformed into a 'genealogical scale of development'; the other, previously situated by ignorance spatially beyond Europe, was now defined by historical evolution before Europe. ${ }^{73}$

\section{Progress and its antitheses}

Just as the invention of European civilization demanded a temporalization of non-European others, so its future was to be secured by identification and hence control - of the most potent threats to its progress. Having explored the intellectual origins of Western slavery and abolition, ${ }^{74}$ David Brion Davis stood back to reflect on the value of recomposing their entire history 'around the theme of changing conceptions of progress'. ${ }^{75}$ The result was a study that charted the momentous transformation from a consciousness of slavery as progressive to that of abolition as progressive. Since the first incursions of European traders into Africa during the fifteenth century, he argues, modern slavery was seen as a progressive force for change. The slave trade was driven not by adventurers, but by European merchants and financiers operating at the very heart of Western modernization. Black slavery, therefore, was absolutely integral to the growth of capitalism. Furthermore, enslavers justified their endeavours, even derived satisfaction from them, in the knowledge that enslavement liberated Africans from primitive paganism and ignorance. In the second half of the eighteenth century new conceptions of progress compelled influential sections of religious, manufacturing and political opinion to press for the abolition of the trade and emancipation of slaves. Britain was the focus of their activities, and since the country was fast emerging as the great commercial centre of the world, anti-slavery came to be articulated with modern progress, slavery with historical regression.

Conceptions of progress have also framed scholarly interpretations of the experience of slavery. Working within a stages theory of development, 
writers as diverse as Adam Smith, Karl Marx, August Comte and certain Christian abolitionists viewed slavery as an early but necessary phase in societal evolution. In previous eras it had enhanced productivity by enforcing labour discipline; indeed, all the great phases of imperial expansion had been accompanied by the enslavement of captives on previously unprecedented scales. By the eighteenth century, however, slavery was perceived by theorists of the stages theory of development as a wasteful and historically anachronistic form of labour. More recently, Eric Williams argued in his brilliantly polemical Capitalism and Slavery that black slavery financed the industrial revolution until it was recognized to hinder further expansion, at which point it was abolished. ${ }^{76}$

For eighteenth-century theorists of progress, slavery represented an alltoo-immediate problem, for while offering validation of societal development it forced recognition of the human costs. Thus the vision of the New World which provided the focus for so much of their thinking was increasingly clouded by records of the suffering inflicted on the native populations and transported slaves, upon whose labour the miracle had depended. The pernicious consequences of the slave trade as an obstacle to progress entered forcefully onto the agenda of 'progressive' thinkers, appearing not only in conventional tracts, sermons and treatises, but also in the imaginative literature of late eighteenth-century Britain. ${ }^{77}$

To understand the nature of this profound transformation we would need to examine in depth its moral, economic and political dimensions. Instead, I wish to consider aspects that touch more directly on the putative connections between anti-slavery sentiment and concern over poverty and colonialism. If connections existed they did so because they were framed by the interests of an emergent capitalist world order. To acknowledge this is not necessarily to fall prey to a crude reductionism. The rise of abolition sentiment, for example, as Brion Davis has so cogently demonstrated, cannot be seen unproblematically as serving the interests of an industrial bourgeoisie, not least because as a class they fiercely resisted moves to end the slave trade. He concludes:

The decision [in 1833] to free 780,000 colonial slaves and compensate their owners was not the result of some Machiavellian design to disguise an ulterior goal. It was the response of a conservative government, representing a defensive aristocracy, to the competing claims that reformers and planters voiced against a backdrop of economic crisis and potential revolution. ${ }^{78}$

Mutatis mutandis, similar arguments can be made for the period leading up to the abolition of the slave trade itself in 1806. What, however, were the claims made by reformers in this period, and how can they be linked to other moral and political concerns? From ancient times various millennialist sects had provided the only concerted opposition to slavery. 


\section{THE ANTINOMIES OF PROGRESS}

From a primitivist belief in the essential goodness of humankind, they sought a life free from sin and human exploitation in all of its forms, and anticipated an age when man would be emancipated from servitude. Persecuted by religious and political authorities, these sectarians were eventually driven into the wilderness, but something of their teaching survived among Quakers, providing their impulse against modern slavery. Their pursuit of human perfectibility and a life free from sin found practical realization through the considerable institutional and economic power they wielded. The decision in the mid eighteenth century to abandon all links with the slave trade, however, was predicated on complex developments in the culture of British Protestantism that promoted anti-slavery sentiment:

1 The place of servitude in the natural order was questioned by social philosophers who were encouraged by the dictates of reason to think anew about the putative certainties of the chain of being.

2 A sensibility of benevolence emerged in reaction to the apocalyptic visions of Calvin and Hobbes that stressed human goodness and perfectibility. Slaves, as innocents and victims, invoked particular compassion in the quest to rid the world of sin.

3 Evangelical currents within Anglicanism and Nonconformity held all to account for personal responsibility, thereby alerting people to the dangers of moral complacency, and marking the peculiar significance of genuine conversion.

4 Primitivism conferred positive images on slaves as inherently virtuous and sensitive, simultaneously serving to counterbalance patterns of prejudice that had previously isolated them from sympathy and identification. ${ }^{79}$

The intellectual and cultural landscape of abolitionism was defined initially by a convergence of these shifts in consciousness, but their influence was mediated by a complex relationship with the more secular belief system of the Enlightenment. The highly ambiguous stance that many Enlightenment thinkers took on the question of slavery suggested that anti-slavery sentiment did not follow automatically from their defence of natural rights. The truth was that thinkers considered to be part of the Enlightenment traversed the political spectrum. Thus the fierce denunciations of slavery in the writings of, say, Rousseau and Abbe Raynal have to be set against the conservative leanings of Hume and Montesquieu.

Clear also is the extent to which Enlightenment thought drew upon visions of the social order that had traditionally been the province of religious orthodoxy, with perhaps surprisingly 'unprogressive' consequences. Gordon Turnbull, who in writing a vindication of slave owners drew inspiration from Hume and Montesquieu, used the chain of being with as 
much effect as had the most conservative clerics in defending the social order:

\begin{abstract}
NEGRO slavery appears, then, to be, as far as reason can judge, one of those indispensable and necessary links, in the great chain of causes and events, which cannot and indeed ought not to be broken; or, in other words, a part of the stupendous, admirable, and perfect whole, which, if taken away, would leave a chasm, not [to] be filled up by all the wit or wisdom of erring and presumptuous man. ${ }^{80}$
\end{abstract}

More representative of the dilemmas of enlightened thought was the figure of Edmund Burke. Burke found it difficult to reconcile a belief in the sanctity of the natural order with the horrors of slavery. 'If the African trade could be considered with regard to itself only, and as a single object, I should think the utter abolition to be on the whole more advisable than any scheme of regulation and reform', he wrote to Henry Dundas in 1792, prefacing his Sketch of a Negro Code ${ }^{81}$ Immediate abolition, however, would be an affront to social equilibrium. His solution, consistent with evolution over time, was gradualism:

I [am] of the opinion ... that a gradual abolition of slavery in the West Indies ought to go hand in hand with anything which should be done with regard to its supply from the coast of Africa.... It is not that my plan does not lead to the extinction of the slave trade, but it is through a very slow progress, the chief effect of which is to be operated in our own plantations, by rendering ... all foreign supply unnecessary. It was my wish, whilst slavery continued, and the consequent commerce, to take such measures as to civilize the coast of Africa by the trade, which now renders it more barbarous, and to lead by degrees to a more reputable, and, possibly, a more profitable connection with it, than we maintain at present. ${ }^{82}$

Strictures against immediate abolition, especially were it to be of a violent nature, were pervasive even among the most radical elements of enlightened opinion. ${ }^{83}$ Thus few were willing to abandon entirely the conservative implications of the chain of being. Raynal's belief in human progress, for example, failed to prevent him adopting a gradualist approach to abolition similar to Burke's, except that freedom from slavery was planned through discrete phases rather than simply encouraged to grow organically.

For the more pessimistic, the spectre of moral decay stalked. Luxury and the unrestrained pursuit of wealth that had brought the Iberian empire down now threatened those European slave-trading nations that had destroyed Amerindians and had turned to Africa ${ }^{84}$ This pessimism, however, was increasingly challenged in principle by the belief that the desire for gain was essential to civilization. The task for philosophers after Mandeville was to find a middle ground. They sought it in Turgot's stages 


\section{THE ANTINOMIES OF PROGRESS}

theory of societal evolution, and from its seductive teleology of progress found reassurance that regressive tendencies would be overwhelmed by the laws of development. None found it more so than Adam Smith, who in defining an identity between morality and utility launched a scathing attack on slavery. Slavery, according to Smith, was a crime against utility and humanity since it threw people into dehumanizing, corrupting and wasteful forms of labour; abolition would unblock the restriction and pave the way to future progress through untrammelled operation of the commercial market.

Finally, anti-slavery sentiment was fostered by an increased sensitivity in the latter half of the eighteenth century to its antithesis, namely, liberty. English notions of a common good based on order, hierarchy and monarchy were dismantled by the American revolution. For Americans freed from British rule, these notions were obsolete, and they set about constructing a society organized around the principles of equality, consent and respect. ${ }^{85}$ In England, on the other hand, the common good survived more or less intact, only then to be assailed by strands of radical opinion imbued with the example of America and ready to struggle for alternatives. At the centre of the struggle were those Nonconformists and latitudinarian Anglicans who were in the vanguard of abolition. That many saw these causes as one was due to their profound belief in liberty of thought, and in the critical role that the moral, rational and freely inquiring citizen had to play in constructing a new community. This natural right to freedom found 'slavery' in all its forms a violation of natural rights that had to be eradicated. ${ }^{86}$ Figures such as Granville Sharp and Richard Price who inhabited this moral universe were instrumental in laying down and campaigning for its precepts. Sharp, for example, secured the notable Mansfield judgement of 1772 whereby black slaves were free the moment they stepped on British soil. This victory, however, was seen merely as a prelude to the universalization of the right to freedom across the empire, even if imperial unity was compromised in the process. ${ }^{87}$ From this complex and shifting intellectual landscape, marked by a certain convergence of religious, social, economic and political currents, arose a sense that slavery 'might symbolize all the forces that threatened the true destiny of $\operatorname{man}^{\prime} .88$

Slavery, however, was not the only matter of intense concern in late eighteenth-century Britain. As we have seen, poverty and colonial expansion were also perceived as barriers to progress, and the ways in which these were articulated and defined as such bore striking similarities to the discursive construction of slavery. Given that the same agencies were responsible, and that they drew upon common intellectual resources and vocabularies, this can come as no surprise. Political economy provided the most compelling framework within which connections could be identified 
and developed. Smith's aim was to remove those artificial restrictions and practices that hampered the free play of the market and hence of the realization of individual self-interest. On these grounds he justified the abolition of slavery as well as the removal of the poor laws and the settlement laws. ${ }^{89}$ The rise of anti-slavery sentiment, therefore, was accompanied by a transformation in attitudes toward poor relief and labour discipline, heralding what many have subsequently perceived as a harsher and less sympathetic sensitivity to the poor. And those who were most vigorous in the denunciation of traditional paternalism - Pitt, Burke, Frederick Eden, John Townsend, Bentham and Malthus - also opposed the slave trade, even though they were determined to distinguish between slavery and poverty as problems requiring urgent attention..$^{90}$

Evangelicals provided the clearest evidence of a concern - realized in practical action - that embraced the plight of slaves and the poor. The massive intervention by evangelical organizations into the lives of the London poor was launched, significantly, in the aftermath of the abolition of slavery, but its lineages can be traced to the late eighteenth century. ${ }^{91}$ Members of the Clapham Sect who were in the vanguard of the abolition movement provided the focus. Thus a group around Wilberforce, including Thomas Bernard, Matthew Martin and Patrick Colquhoun, established in 1796 the Society for Bettering the Condition and Increasing the Comforts of the Poor. Its professed aim was to examine 'everything that concerns the happiness of the poor' so that

in proportion as we can multiply domestic comforts, in the same degree we may hope to promote the cause of morality and virtue.... Let us give effect to that master spring of action, on which equally depends the prosperity of individuals and empire - THE DESIRE IMPLANTED IN THE HUMAN BREAST OF BETTERING ITS CONDITION. ${ }^{92}$

Here was an ethos of progress that owed much to the influence of Smith, but at the same time it was one that attempted to overcome the divergence already apparent in political economy between moral and material sentiment. The poor, it was argued, needed active encouragement to improve themselves through self-help, industry and frugality. For those who could not work, the harsh deterrence of the poor law was inappropriate. If genuine cases of distress were revealed through the systematic gathering of reliable information, then liberal scales of relief and instruction could be made available which would promote self-sufficiency and bring a permanent improvement. ${ }^{93}$ Under such circumstances the poor would be rescued from moral degeneration, and evangelicals sleep easy in the knowledge that they had sought sanctification through good work. As Thomas Chalmers, who was to lay the theoretical foundation for evangelical work in the nineteenth-century metropolis, wrote: 'I should count the 
salvation of a single soul of more value than the deliverance of a whole empire from pauperism' ${ }^{94}$

What is revealing about this statement is less its evident exaggeration than the fact that Chalmers thought fit to make reference to empire in a discussion of pauperism. For the matter of empire was of heightened concern to evangelicals in the late eighteenth century; indeed, in certain crucial respects their endeavours overseas predated and prefigured those in the domestic urban context. The chronology of missionary activity is instructive. Prior to the close of the eighteenth century, a variety of organizations had been established to undertake the work of Christianity abroad, although only in the widest possible sense could these be seen as missionary. The Society for Promoting Christian Knowledge was formed in 1699, ostensibly to publish religious works, but later provided limited financial support for missionary work in South India. And the Society for Propagation of the Gospel in Foreign Parts, formed in 1701, supported chaplains to expatriate communities abroad. Missionary work with indigenous peoples was rarely pursued, except on the personal initiative of individual priests, ${ }^{95}$ until the 1790s when evangelical impulses within Nonconformity and Anglicanism gave birth to the Baptist Missionary Society (1792), the London Missionary Society (1795) and the Church Missionary Society (1799).

Relationships between evangelicalism and the imperial 'project' are too complex to allow ready generalization. ${ }^{96}$ It is clear, however, that in the case of India missionary activity was viewed with rather more sympathy by the East India Company than is conventionally thought. Charles Grant, for example, was a director of the Company and a leading advocate of state intervention in the religious affairs of India. His object to plant English culture in Indian soil determined the agendas of most British evangelicals and officials from the late eighteenth century. ${ }^{97}$ Furthermore, he knew members of the Clapham Sect, including Wilberforce, with whom he attempted during the 1793 debate on the renewal of the Company's charter to introduce a clause requiring it to finance missionary activity.

Imperial progress on the fronts of slavery, poverty and colonialism was conceptualized by agents operating across their narrowly defined boundaries using an intellectual and linguistic repertoire forged from the transformation in human consciousness that occurred late in the eighteenth century. Structural barriers were perceived, but these tended to assume less significance than the threats posed by the persistence of paupers and colonial subjects. How these threats were constructed discursively in the long nineteenth century as a means of understanding and hence controlling them is what I wish to address in the following chapters. 


\section{THE OTHER EMPIRE}

\section{Notes}

1 An extensive literature now covers these issues, but see especially C.A. Bayly, Imperial Meridian. The British Empire and the World, 1780-1830, London, Longman, 1989; John Brewer, The Sinews of Power. War, Money and the English State, 1688-1783, London, Unwin Hyman, 1989; Linda Colley, Britons. Forging the Nation, 1707-1837, London, Pimlico, 1994; and Kathleen Wilson, A Sense of the People. Politics, Culture and Imperialism in England, 1715-1785, Cambridge, Cambridge University Press, 1998.

2 The definition is that of David Spadafora, The Idea of Progress in Eighteenth-Century Britain, New Haven, Yale University Press, 1990, p. 6. I am indebted to him for what follows on religious thought.

3 Ibid., p. 19.

4 Spadafora does seem to anticipate such criticism: 'Compared to the forms of ideas [in the arts and sciences and in religion], doctrines of economic and political progress, considered on their own, were not nearly as common.... [T] he belief in progress in the political and social realms was necessarily an integral part of the notions of general progress' (ibid., p. 12). As I hope to demonstrate, this was not always the case.

5 This whole question is examined with exemplary scholarship by Mary Poovey, $A$ History of the Modern Fact. Problems of Knowledge in the Sciences of Wealth and Society, Chicago, University of Chicago Press, 1998.

6 Ibid., p. 174.

7 The best account of this remains Michael McKeon, The Origins of the English Novel, Baltimore, The Johns Hopkins University Press, 1987.

8 This telling phrase is from Gertrude Himmelfarb, The Idea of Poverty. England in the Early Industrial Age, London, Faber, 1984, p. 18.

9 Ibid., p. 3. For other discussions, see J.R. Poynter, Society and Pauperism. English Ideas on Poor Relief, 1795-1834, London, Routledge, 1969; R. H. Tawney, Religion and the Rise of Capitalism, London, Pelican, 1948 [1926]; S. Woolf, The Poor in Western Europe in the Eighteenth and Nineteenth Centuries, London, Methuen, 1986.

10 Tawney, Religion and the Rise of Capitalism, p. 114.

11 For an authoritative survey of the eighteenth century, paying due regard to moral and economic concern, see Richard Sheldon, 'The politics of bread in eighteenth-century England', unpublished PhD thesis, University of Birmingham, 2000.

12 Poynter, Society and Pauperism, p. 21.

13 Daniel Defoe, Giving Alms No Charity, and Employing the Poor a Grievance to the Nation, London, 1704, cited in Himmelfarb, The Idea of Poverty, p. 26.

14 Bernard Mandeville, The Fable of the Bees. Private Vices, Public Benefits, London, Roberts, 1714, cited in Himmelfarb, The Idea of Poverty, p. 28. The sense of shock witnessed on its publication was created less by Mandeville's attack on the poor than by the uncomfortable recognition that his vehemence was directed also to the rich who were responsible for the great villainies.

15 Thomas Alcock, Observations on the Defects of the Poor Laws ..., London, Baldwin, 1752, cited in Poynter, Society and Pauperism, p. 30.

16 Himmelfarb, The Idea of Poverty, pp. 50-63.

17 The provision of relief under other aspects of the poor law, on the other hand, was supported by Smith. This may have been a move prompted by the moral philosopher rather than the political economist, but it singled Smith out at a time when the putative evils of the poor law system were viewed with heightened anxiety elsewhere.

18 A.L. Beier, Masterless Men. The Vagrancy Problem in England, 1560-1640, London, Methuen, 1985.

19 Christopher Hill, Liberty against the Law. Some Seventeenth-Century Controversies, London, Allen Lane, 1996; N. Rogers, 'Policing the poor in eighteenth-century London: the vagrancy laws and their administration', Histoire Sociale-Social History, 24:43, 1991, pp. 127-47.

20 Beier, Masterless Men, p. 132.

21 John Marriott, 'The spatiality of poverty in eighteenth-century London', in Tim 


\section{THE ANTINOMIES OF PROGRESS}

Hitchcock and Heather Shore (eds), The Streets of London, London, Rivers Oram, 2003.

22 For most of what follows I have relied heavily on the monumental work of David Brion Davis, in particular The Problem of Slavery in Western Culture, New York, Oxford University Press, 1988 [1966], and Slavery and Human Progress, New York, Oxford University Press, 1984.

23 Brion Davis, The Problem of Slavery in Western Culture, pp. 118-21.

24 Ibid., p. 336.

25 Brion Davis, Slavery and Human Progress, pp. 382-90.

26 Ibid., p. 388.

27 Brion Davis, The Problem of Slavery in Western Culture, pp. 433-4.

28 Clare Midgely, Woman Against Slavery. The British Campaign, 1780-1870, London, Routledge, 1992.

29 Take, for example, Anthony Trollope's travel account The West Indies and the Spanish Main, London, Chapman and Hall, 1859, which had such a decisive impact on postabolition thought. Slavery, he argued, had led to a forced encounter of black people with a superior race, leading inevitably to progress. Emancipation, however, had provided former slaves with freedom from work, rather than a continued desire for progress. Left to themselves, they would regress into the barbarism from which enslavement had rescued them (Catherine Hall, Civilising Subjects. Metropole and Colony in the English Imagination, 1830-1867, London, Polity, 2002, p. 217).

30 Patrick O'Brien, 'Inseparable connections: trade, economy, fiscal state, and the expansion of empire, 1688-1815', in P.J. Marshall (ed.), The Oxford History of the British Empire. Vol. II. The Eighteenth Century, Oxford, Oxford University Press, 1998.

31 Brewer, The Sinews of Power, p. 175.

32 Bayly, Imperial Meridian, p. 2.

33 Anthony Pagden, Lords of all the World. Ideologies of Empire in Spain, Britain and France, c.1500-c.1800, New Haven, Yale University Press, 1995, p. 25.

34 A useful edition with an introduction by Anthony Pagden has recently appeared: Bartolome de Las Casas, A Short Account of the Destruction of the Indies, London, Penguin, 1992.

35 Pagden, Lords of All the World, p. 6.

36 David Hume, 'Of the study of history' (1741), cited in David Armitage, The Ideological Origins of the British Empire, Cambridge, Cambridge University Press, 1999, p. 191.

37 Unsurprisingly, the language was that of some of the most strident critics of empire, notably Condorcet, Hume, Diderot, Raynal and Smith (Pagden, Lords of All the World, p. 160). That this language was used to perpetuate European imperialism, albeit in a different guise, is another example of the ambiguous legacy of the Enlightenment, criticized so forcefully by postcolonial writings.

38 Armitage, The Ideological Origins of the British Empire, p. 8.

39 Jack P. Greene, 'Empire and identity from the Glorious Revolution to the American Revolution', in Marshall (ed.), The Oxford History of the British Empire. Vol. II, p. 214.

40 S. Ambirajan, Classical Political Economy and British Policy in India, Cambridge, Cambridge University Press, 1978, p. 2. Ambirajan makes a persuasive case for the influence of political economy on imperial policy in India, but adds the necessary caveat that 'it is extremely difficult to determine whether the arguments based on economic ideas were aids to reach a particular decision or were mere ancillary arguments used to buttress policies already adopted as a result of other non-doctrinal reasons' (p. 18).

41 Ibid., p. 175.

42 For a fascinating discussion of the changing political rhetoric of state and empire in the eighteenth century, see Peter Miller, Defining the Common Good. Empire, Religion and Philosophy in Eighteenth-Century Britain, Cambridge, Cambridge University Press, 1994.

43 Bayly, Imperial Meridian, p. 108.

44 The terms are respectively those of Armitage, The Ideological Origins of the British 


\section{THE OTHER EMPIRE}

Empire, and Bayly, Imperial Meridian.

45 Pagden, Lords of All the World, p. 9.

46 Arthur O. Lovejoy, Reflections on Human Nature, Baltimore, The Johns Hopkins Press, 1961, p. 22.

47 For a recent cogent and accessible survey, see Kenan Malik, The Meaning of Race. Race, History and Culture in Western Society, Basingstoke, Macmillan, 1996.

48 Spadafora, The Idea of Progress, p. 331.

49 These seemingly disparate intellectual developments have been summarily dismissed by Spadafora as 'too vast to rest comfortably on the usually slender supporting evidence on which they rest' (The Idea of Progress, p. 321). Instead, he elects to focus on narrower doctrines of progress that commanded the attention of most of the seminal thinkers in Britain both before and after 1750. The triumph of the modern over ancients in the arts and sciences, the pliability of human nature, particularly in the recognition of the critical role of nurture, the influence of linguistic development, and improvement in religious knowledge, he claims, dominated the writings of people as diverse as David Hume, Lord Kames, Richard Price, Adam Smith, Joseph Priestley and William Robertson. While not wishing to question the fine detail of these arguments, it seems to me that the narrow focus is too limiting. The neglect of doctrines of political and economic progress, of broader traditions of Enlightenment thought, and of more popular manifestations in prose and poetry severely circumscribes an appreciation of the impact of progress on British thought. Most significantly for this study, it provides no insight into how conceptions of progress were linked to the rigidification of class and racial hierarchies in the late eighteenth century.

50 Arthur O. Lovejoy, The Great Chain of Being. A Study of the History of an Idea, Cambridge, Harvard University Press, 1961, p. 59. Although based on lectures given at Harvard University in 1933, the book remains the most lucid and thorough exploration of the idea.

51 Ibid., pp. 190, 194.

52 Ibid., p. 200.

53 Lois Whitney, Primitivism and the Idea of Progress in English Literature of the Eighteenth Century, Baltimore, The Johns Hopkins University Press, 1934, p. 142.

54 Lovejoy, The Great Chain of Being, p. 234.

55 For studies of this concept, see John Sekora, Luxury. The Concept in Western Thought, Eden to Smollett, Baltimore, The Johns Hopkins University Press, 1977, and Christopher Berry, The Idea of Luxury. A Conceptual and Historical Investigation, Cambridge, Cambridge University Press, 1994. Although Sekora's claim that luxury was 'the single most significant social and political idea of eighteenth-century England' (p. 9) overstates the case, this is not to deny its considerable importance. Among the writers who considered luxury were Mandeville, Addison, Defoe, Pope, Swift, Fielding, Hume, Johnson, Gibbon, Wesley and Adam Smith (p. 2).

56 Berry, The Idea of Luxury, p. xx.

57 John Brown, Estimate of the Manners and Principles of the Times, Dublin, Faulkener, Hoey and Exshaw, 1758, pp. 16, 20.

58 Ibid., p. 111.

59 Lovejoy, Reflections on Human Nature, p. 16.

60 Ibid., pp. 170-3.

61 Arthur O. Lovejoy, 'Foreword', in Whitney, Primitivism and the Idea of Progress, p. xii.

62 Cited in ibid., p. 179.

63 Sekora, Luxury, p. 103.

64 Posterity has unfairly regarded Smith as the dour patron saint of laissez-faire, but this tends to neglect the fact that he was a moral philosopher of some note. His Theory of Moral Sentiments is described by Lovejoy as 'the most original and systematic eighteenth-century inquiry concerning the motivations of human behaviour' (Reflections on Human Nature, p. 190).

65 Cited in Lovejoy, Reflections on Human Nature, p. 215.

66 Ronald Meek, Social Science and the Ignoble Savage, Cambridge, Cambridge University Press, 1976, p. 6. 


\section{THE ANTINOMIES OF PROGRESS}

67 Ibid., p. 22.

68 Ibid., pp. 220-1.

69 Ibid., p. 33.

70 Thomas C. Patterson, Inventing Western Civilization, New York, Monthly Review Press, 1997.

71 In what follows I have brought together the useful but conflicting perspectives found in Margaret Hodgen, Early Anthropology in the Sixteenth and Seventeenth Centuries, Philadelphia, University of Pennsylvania Press, 1964, and Bernard McGrane, Beyond Anthropology. Society and the Other, New York, Columbia University Press, 1989, overall tending to favour the more dynamic approach of the former.

72 Hodgen, Early Anthropology, pp. 389-90.

73 McGrane, Beyond Anthropology, p. 94.

74 Brion Davis, The Problem of Slavery in Western Culture, and The Problem of Slavery in the Age of Revolution, 1770-1823, Ithaca, Cornell University Press, 1975.

75 Brion Davis, Slavery and Human Progress, p. xix.

76 Ibid., p. xiv.

77 For a collection of primary texts from the Romantic age, which does indicate usefully the extent to which the problem of slavery entered into the cultural fabric of British life, see Peter Kitson and Debbie Lee (eds), Slavery, Abolition and Emancipation. Writings in the British Romantic Period, 6 vols, London, Pickering and Chatto, 1999.

78 Brion Davis, Slavery and Human Progress, p. 222.

79 Brion Davis, The Problem of Slavery in the Age of Revolution, pp. 44-8.

80 Gordon Turnbull, An Apology for Negro Slavery; or, the West-Indian Planters Vindicated from the Charge of Inhumanity, London, 1786, cited in Brion Davis, The Problem of Slavery in Western Culture, p. 392.

81 Edmund Burke, 'A Letter to the Right Hon. Henry Dundas, one of His Majesty's Principal Secretaries of State. With the Sketch of a Negro Code', in The Works and Writings of the Right Hon. Edmund Burke, 12 vols, London, John Nimmo, 1899 [1792], Vol. VI, p. 257.

82 Ibid., p. 259.

83 Brion Davis, The Problem of Slavery in Western Culture, p. 399.

84 Ibid., p. 423.

85 Miller, Defining the Common Good, p. 16. These principles, of course, did not apply to native Indians or slaves.

86 It has to be remembered that slavery as a term was commonly used to describe all forms of servitude and bondage. This lack of discrimination was to have dire consequences for abolitionists since they often found themselves opposed by otherwise radical elements who argued that the 'white slaves' in British mines and factories had to be freed before the black slaves on plantations.

87 Miller, Defining the Common Good, p. 293.

88 Brion Davis, The Problem of Slavery in Western Culture, p. 445.

89 Brion Davis, The Problem of Slavery in the Age of Revolution, p. 353.

90 Ibid., p. 358.

91 See my Introduction to John Marriott and Masaie Matsumura (eds), The Metropolitan Poor. Semi-Factual Accounts, 1795-1910, 6 vols, London, Pickering and Chatto, 1999.

92 Report of the Society, I (1798), cited in J.R. Poynter, Society and Pauperism. English Ideas on Poor Relief, 1795-1834, London, Routledge, 1969, p. 91.

93 Ibid., p. 96.

94 Chalmers to John Brown, 1819, cited in Boyd Hilton, The Age of Atonement. The Influence of Evangelicalism on Social and Economic Thought, Oxford, Clarendon Press, 1988, p. 88.

95 Andrew Porter, 'Religion, missionary enthusiasm, and empire', in Andrew Porter (ed.), The Oxford History of the British Empire. Vol. III. The Nineteenth Century, Oxford, Oxford University Press, 1999, p. 228.

96 See, for example, T. Thomas, 'Foreign missions and missionaries in Victorian Britain', in J. Wolffe (ed.), Religion in Victorian Britain. Vol. V. Culture and Empire, Manchester, Manchester University Press, 1997, and Chapter 4 below. 


\section{THE OTHER EMPIRE}

97 Ainslie Embree, 'Christianity and the state in Victorian India: confrontation and collaboration', in R.W. Davis and R.J. Helmstadter (eds), Religion and Irreligion in Victorian Society, London, Routledge, 1992, p. 157. 